\title{
Feline subcutaneous pythiosis
}

\author{
Luciana Maria Curtio Soares ${ }^{1}$ (D) Diego Montagner Schenkel ${ }^{1}$ Janaina Marcela Assunção Rosa $^{2}$ \\ Ludmila Silva Azevedo ${ }^{3}{\text { Tainara Renata } \text { Tineli }^{4} \text { Valéria Dutra }^{2} \text { (D) Edson Moleta Colodel }}^{1}$ \\ Caroline Argenta Pescador ${ }^{1^{*}}$
}

${ }^{1}$ Laboratório de Patologia Veterinária, Faculdade de Medicina Veterinária (FAVET), Universidade Federal de Mato Grosso (UFMT), 78060-900, Cuiabá, MT, Brasil. E-mail: carolpescador@yahoo.com.br. ${ }^{*}$ Corresponding author.

${ }^{2}$ Laboratório de Microbiologia, Faculdade de Medicina Veterinária (FAVET), Universidade Federal de Mato Grosso (UFMT), Cuiabá, MT, Brasil. ${ }^{3}$ Setor de Diagnóstico por Imagem, Faculdade de Medicina Veterinária (FAVET), Universidade Federal de Mato Grosso (UFMT), Cuiabá, MT, Brasil. ${ }^{4}$ Universidade Federal de Santa Catarina (UFSC), Campus de Curitibanos, SC, Brasil.

ABSTRACT: Pythiosis in felines is a rare disease associated with the oomycete Pythium insidiosum. The aim of this report was to describe the macroscopic, histopathological, and molecular characteristics of P. insidiosum infection in a 2-year-old cat, with a localized invasive subcutaneous mass. The feline had an increase of volume near the anal region since it was younger. The cat died just after surgery. The necropsy was performed, and samples were collected for histopathological examination. Microscopically, the skin lesion was characterized by necroeosinophilic dermatitis, panniculitis, and myositis surrounding negatively stained hyphal structures. In the sections stained with GMS, dark brown hyphae were clearly seen inside the affected tissue. They were rarely septate and their walls were almost parallel. Immunohistochemistry using a polyclonal anti-P. insidiosum antibody showed a strongly immunostained hyphae into the lesions. The analysis based on PCR had a positive result for $P$. insidiosum. Pythiosis should be considered in the differential diagnosis of subcutaneous tissue disorders in felines.

Key words: Pythium insidiosum, diagnostic, cat.

Pitiose subcutânea em um felino

RESUMO: Pitiose em felinos é uma doença de ocorrência rara associada ao oomiceto Pythium insidiosum. O objetivo deste relato é descrever as características macroscópicas, histopatológicas e moleculares da infecção por P. insidiosum em um gato de dois anos de idade, com uma massa invasiva localizada no subcutâneo. O gato morreu logo após a cirurgia, sendo realizada a necropsia e coleta de amostras para exame histopatológico. Microscopicamente, a lesão cutânea foi caracterizada por dermatite necroeosinofilica, paniculite e miosite envolvendo imagens de hifas negativamente coradas. Nas seções coradas com GMS, hifas marrom-escuras foram claramente vistas dentro do tecido afetado. As hifas raramente eram septadas e suas paredes eram quase paralelas. A imuno-histoquimica, utilizando um anticorpo policlonal anti-P. insidiosum, mostrou hifas fortemente imunomarcadas nas lesões. A análise baseada em PCR teve resultado positivo para P. insidiosum. A pitiose deve ser considerada no diagnóstico diferencial de desordens teciduais subcutâneas em felinos.

Palavras-chave: Pythium insidiosum, diagnóstico, gato.

Pythium insidiosum belongs to the Kingdom Stramenopila, Phylum Oomycota, Family Pythiaceae, Genus Pythium. There are at least 120 Pythium species reported (MENDONZA \& NEWTON, 2005). $P$. insidiosum is the most common etiological agent associated with pythiosis in mammals. It is a rare noncommunicable disease usually reported in tropical, subtropical, and temperate regions (GAASTRA et al., 2010). In Brazil, pythiosis is more common in equids, and lesions are more commonly reported in the distal extremities of the limbs, thorax, and ventral abdomen, because of frequent contact with water contaminated with zoospores (SANTURIO et al., 2008). However, sporadic cases showing widespread lesions in the skin, nostrils, lymph nodes, lungs, spleen, and liver have already been reported (REIS et al., 2003). Feline pythiosis is rare and lesions are usually restricted to the skin and subcutaneous tissues. There is no predisposition to breed, age, or sex (GAASTRA et al., 2010). The first report of a feline $P$. insidiosum infection was in 1991, where a mass inside the nasal fossae and nasopharynx, extending to both orbital cavities was reported (BISSONNETTE et al., 1991). According to GROOTERS et al. (2003), young cats aged less than 10 months are most commonly affected, presenting with lesions in the subcutaneous tissue, inguinal and 
periorbital regions, tail base, and sometimes in claws and paws. Recently, a case of sublingual pythiosis was reported in a cat (FORTIN et al., 2017). In Brazil, a retrospective study on the occurrence of mycoses and pythiosis in domestic animals by GALIZA et al. (2014) showed a single case where a cat had lesions that affected the gastrointestinal tract, including the small intestine, pancreas, liver, and mesenteric lymph nodes.

The objective of this report was to describe the macroscopic, histopathological, and molecular characteristics of a localized invasive subcutaneous $P$. insidiosum infection in a 2-year-old female cat, undefined breed, which was taken to the Veterinary Hospital of the Federal University of Mato Grosso, Campus Cuiabá, with a history of volume increase near the anal region since it was younger. Ten months before the cat had clinical signs of dystocia and consequently cesarean section was performed. A few months later, the mass evolved reaching approximately $10 \mathrm{~cm}$ in diameter. Clinical examination showed that the mass involved the lateral and dorsal portions of the anus and that its consistency was soft in the peripheral region and firm in the central region. Sonographic examination of the perianal region showed that the mass was heterogeneous, with anechoic content and a cavitary surface, positive with color Doppler, with indefinite contour and shape, suggestive of neoplasia. During the surgical mass excision, the tumor was found to involve the rectum bilaterally and externally and was adhered to adjacent structures, which hindered its removal with surgical safety margins. Mass fragments were sent for histopathological analysis in 10\% formalin solution.

The animal died in the postoperative period and was subsequently necropsied. Macroscopic examination showed fragments of brownish, friable, and lobulated brown masses on the inner surface of the pelvic region, as well as hematomas in the subcutaneous tissue surrounding the surgical incision. Microscopic examination showed that the fragments removed during the surgery revealed multifocal areas of necrosis and eosinophilic material (similarly to the Splendore-Hoeppli reaction) with negative images, morphologically suggestive of hyphae (Figure 1A) in the dermis, panicle, and adjacent musculature. These structures were surrounded by a severe inflammatory infiltrate composed of macrophages with large eosinophilic and foamy cytoplasm (Figure 1B). There were also multinucleated giant cells, neutrophils, and eosinophils, as well as proliferation of connective tissue with marked collagen deposition, characterizing the lesion as dermatitis, panniculitis, and granulomatous myositis. The Grocott's methenamine silver (GMS) staining (Figure 1C), showed hyphae with irregular ramifications and rare septations.

For differential diagnosis of pythiosis, lagenidiosis, and zygomycosis, twoparaffin-embedded sections measuring $10 \mu \mathrm{m}$ of each subcutaneous lesion were sent for molecular characterization. The DNA was extracted from the paraffin sample according to SHI et al. (2004), and PCR was performed according to GROOTERS \& GEE (2002), using the primers PI-1: 5'-TTCGTCGAAGCGGACTGCT-3'; and PI2: 5';-GCCGTACAACCCGAGAGTCATA-3' to amplify a 105-bp section that encoded a sequence of the $P$. insidiosum rDNA ITS1 gene (Figure 1E). The amplified product was analyzed through $2 \%$ agarose gel electrophoresis, and observed on the ChemiDoc ${ }^{\mathrm{TM}}$ XRS documentation system using ImageLab ${ }^{\mathrm{TM}}$ software, with a molecular weight marker of $100 \mathrm{bp}$. The obtained amplicon was purified using a GFX PCR DNA GelBand purification kit and sequenced in the ABI 3500 Genetic Analyzer (Applied Biosystems ${ }^{\circledR}$ ), using specific oligonucleotides. The sequence was analyzed using the BLAST (NCBI) software, obtaining $97 \%$ identity with the $P$. insidiosum sequence (GenBank KP842848).

Immunohistochemistry technique was used in subcutaneous tissue sections with minor modifications, selected according to UBIALI et al. (2013), with the primary anti- $P$. insidiosum antibody (1:500) and incubated at $37^{\circ} \mathrm{C}$ for 2 hours. The secondary antibody used was the alkaline phosphatase conjugate system (MACH 4 Universal AP Polymer Kit - Biocare Medical) and the samples were incubated for $30 \mathrm{~min}$ at room temperature. The chromogen used was Warp Red (Biocare Medical). Sections were counterstained with hematoxylin. The hyphae were marked positive for $P$. insidiosum (Figure 1D).

The diagnosis of $P$. insidiosum was based on clinical, histological, and molecular aspects. Pythiosis, lagenidiosis, and zygomycosis are caused by distinct etiological agents, but with similar clinical and histopathological characteristics (GROOTERS, 2003). Cutaneous pythiosis causes panniculitis, and nodular and ulcerative dermatitis, thus it is recommend the use of deep biopsies rather than superficial biopsies or punches (GROOTERS, 2003). In addition, a diagnosis based on oomycosis and zygomycosis has been historically problematic because the macroscopic lesions associated with pythiosis are easily confused with those caused by neoplasms or bacterial infection, so the tissue is completely fixed and specimens are not collected for 


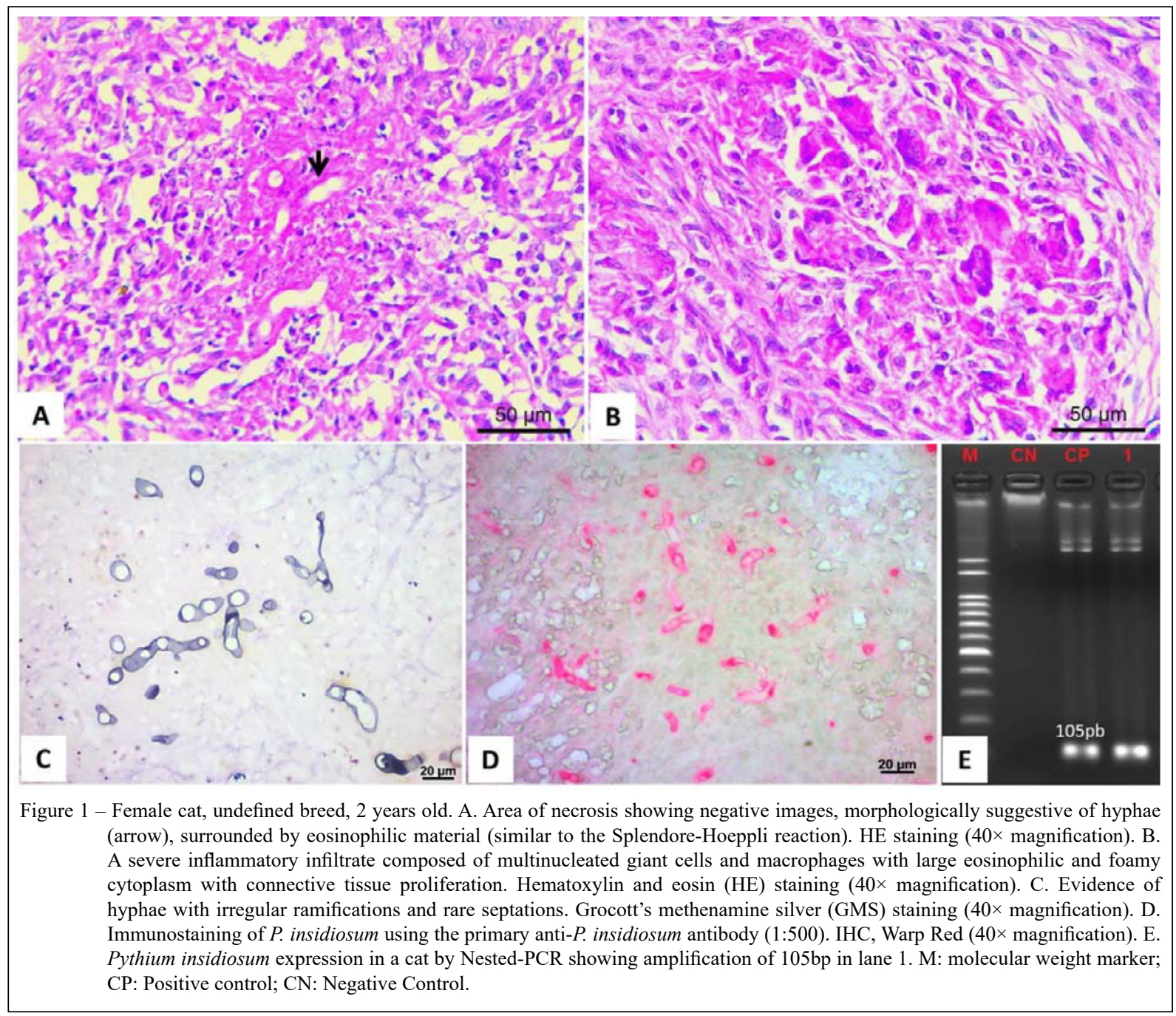

culture (GROOTERS, 2003; RAKICH et al., 2005). In the present case, the initial clinical suspicion was a neoplastic process, so the entire sample was fixed in $10 \%$ formalin, making the microbiological examination impossible. With respect to microscopic features, RAKICH et al. (2005) described two cases of feline pythiosis with lesions in small intestine and mesentery. The lesions were composed of dense fibrous connective tissue stroma containing eosinophils, macrophages, and fewer lymphoid cells with foci of necrosis composed of bright eosinophilic material and nuclear debris. The GMS-stained sections confirmed the presence of few to moderate numbers of hyphae within areas of necrosis. In both cats, there was no formation of distinct granulomas. The morphological lesion observed in the present study was similar to that reported by RAKICH et al. (2005). However, microscopics finds also revealed the presence of granulomatous formations with macrophages with large eosinophilic and foamy cytoplasm and multinucleated giant cells.

The diagnosis in the present study was confirmed by molecular tools and immunohistochemistry procedure. Molecular techniques for diagnosis of infectious diseases in humans and animals have become increasingly important, since they offer greater specificity than the morphological characterization of culture isolates or immunohistochemical labeling of infected tissues (GROOTERS \& GEE, 2002). The literature showed few reported cases of pythiosis in cats (GROOTERS, 2003; RAKICH et al., 2005; FORTIN et al., 2017). 
This case described the manifestation of pythiosis in subcutaneous tissues. Epidemiological data on this case of feline pythiosis were limited and it was uncertain whether the cat had a direct contact with pond water or not. The present cat was an indoor/ outdoor cat which is common in urban Cuiabá municipality environment. Pythiosis in cats is rare and when is diagnosed late tends to evolve in the animal's death. This case suggests that this disease should be included in the differential diagnosis of chronic infections and neoplasias associated with the presence of masses in feline subcutaneous tissues. It also highlighted the importance of tissue biopsy with appropriate diagnostic tools, such as histology, immunohistochemistry and molecular techniques for increasing frequency of diagnosis confirmation of pythiosis.

\section{ACKNOWLEDGEMENTS}

The authors are grateful to Coordenação de Aperfeiçoamento de Pessoal de Nível Superior (CAPES) for financial support.

\section{BIOETHICS AND BIOSSECURITY COMMITTEE APPROVAL}

We authors of the article entitled "Feline subcutaneous pythiosis: A case report" declared, for all due purposes, the project that gave rise to the present data of the same has not been submitted for evaluation to the Ethics Committee of the Universidade Federal do Mato Grosso, but we are aware of the content of the Brazilian resolutions of the National Council for Control of Animal Experimentation - CONCEA "http://www.mct.gov.br/index.php/ content/view/310553.html" if it involves animals.

Thus, the authors assume full responsibility for the presented data and are available for possible questions, should they be required by the competent authorities.

\section{DECLARATION OF CONFLICTING OF INTERESTS}

The authors declare no conflict of interest. The founding sponsors had no role in the design of the study; in the collection, analyses, or interpretation of data; in the writing of the manuscript, and in the decision to publish the results.

\section{AUTHORS' CONTRIBUTIONS}

The authors contributed equally to the manuscript.

\section{REFERENCES}

BISSONNETTE, K.W. et al. Nasal and retrobulbar mass in a cat caused by Pythium insidiosum. Journal of Medical and Veterinary Mycology, v.29, n.1, p.39-44, 1991. Available from:
$<$ https://www.ncbi.nlm.nih.gov/pubmed/1648127>. Accessed: May, $14,2018$.

FORTIN, J.S. et al. Sublingual pythiosis in a cat. Acta Veterinaria Scandinavica, v.59, n.1, p.63, 2017. Available from: <https:// www.ncbi.nlm.nih.gov/pmc/articles/PMC5615467/>. Accessed: May, 14, 2018. doi: 10.1186/s13028-017-0330-z.

GAASTRA, W. et al. Pythium insidiosum: An overview. Veterinary Microbiology, v.146, n.1-2, p.1-16, 2010. Available from: <https:// www.ncbi.nlm.nih.gov/pubmed/20800978>. Accessed: May, 14, 2018. doi: 10.1016/j.vetmic.2010.07.01.

GALIZA, G.J.N. et al. Occurrence of mycoses and pythiosis in domestic animals: 230 cases. Pesquisa Veterinária Brasileira, v.34, n.3, p.224-232, 2014. Available from: <https://dx.doi. org/10.1590/S0100-736X2014000300005>. Accessed: May, 14, 2018. doi: 10.1590/S0100-736X2014000300005.

GROOTERS, A.M. Pythiosis, lagenidiosis, and zygomycosis in small animals. The Veterinary Clinics Small Animal Pratice, v.33, n.4, p.695-720, 2003. Available from: <https://www.ncbi. nlm.nih.gov/pubmed/12910739>. Accessed: May, 14, 2018. doi: 10.1016/S0195-5616(03)00034-2.

GROOTERS, A.M.; GEE, M.K. Development of a nested polymerase chain reaction assay for the detection and identification of Pythium insidiosum. Journal of Veterinary Internal Medicine, v.16, n.2, p.147-152, 2002. Available from: <https://www.ncbi. nlm.nih.gov/pubmed/11899029>. Accessed: May, 14, 2018.

MENDONZA, L.; NEWTON, J.C. Immunology and immunotherapy of the infections caused by Pythium insidiosum. Medical Mycology, v.43, n.6, p.477-486, 2005. Available from: $<$ https://www.ncbi.nlm.nih.gov/pubmed/16320491>. Accessed: May, 14, 2018. doi: 10.1080/13693780500279882.

RAKICH, P.M. et al. Gastrointestinal pythiosis in two cats. Journal of Veterinary Diagnostic Investigation, v.17, n.3, p.262-269, 2005. Available from: <https:/www.ncbi.nlm.nih.gov/ pubmed/15945385>. Accessed: May, 14, 2018.

REIS JR., J.L. et al. Disseminated pythiosis in three horses. Veterinary Microbiology, v.96, n.3, p.289-295, 2003. Available from: <https:// www.ncbi.nlm.nih.gov/pubmed/14559176>. Accessed: May, 14, 2018. doi: 10.1016/j.vetmic.2003.07.005.

SANTURIO, J.M. et al. Granulomatous rhinitis associated with Pythium insidiosum infection in sheep. Veterinary Record, v.163, n.9, p. 276-277, 2008. Available from: <https://www.ncbi.nlm.nih. gov/pubmed/18757907>. Accessed: May, 14, 2018. doi: 10.1136/ vr.163.9.276.

SHI, S.R. et al. DNA extraction from archival formalin-fixed, paraffin-embedded tissues: heat-induced retrieval in alkaline solution. Histochemistry and Cell Biology, v.122, n.3, p.211-218, 2004. Available from: < https://www.ncbi.nlm.nih.gov/pubmed/15322858>. Accessed: May, 14, 2018. doi: 10.1007/s00418-004-0693-x.

UBIALI, D.G. et al. Pathology of nasal infection caused by Conidiobolus lampranges and Pythium insidiosum in sheep. Journal of Comparative Pathology, v.149, n.2-3, p.137-145, 2013. Available from: <http://dx.doi.org/10.1016/j.jcpa.2012.12.002>. Accessed: May, 14, 2018. doi: 10.1016/j.jcpa.2012.12.002. 